\title{
Glipizide versus Tolbutamide, an Open Trial
}

\author{
Effects on Insulin Secretory Patterns and Glucose Concentrations
}

\author{
S. E. Fineberg and S. H. Schneider \\ Thorndike Memorial Laboratories, Boston University School of Medicine, Boston City Hospital, Boston, Massachusetts \\ and Indiana University School of Medicine, Indianapolis, Indiana, USA
}

Summary. An open parallel trial with glipizide or tolbutamide was carried out in a cohort of 29 comparable maturity-onset diabetic patients. Eighteen of these individuals were studied in detail. During six months of active drug therapy the mean decrease in fasting serum glucose levels on glipizide was 25 $\pm 2 \%$ versus $17 \pm 2 \%$ on tolbutamide $(p<0.025)$. Decreases in post prandial glucose levels were 12.2 and $10.4 \%$. Glucose disappearance rates $(\mathrm{Kg})$ during the sixth month of treatment with both drugs increased significantly: on glipizide from $0.47 \pm 0.04 \% / \mathrm{min}$ to $0.85 \pm 0.08 \% / \mathrm{min}(\mathrm{p}<0.005)$, and on tolbutamide from $0.47 \pm 0.08 \% / \mathrm{min}$ to $0.70 \pm 0.11 \% / \mathrm{min}(\mathrm{p}<0.01)$. Early and late insulin release (summed increases over basal for $2-10 \mathrm{~min}$ and $10-60 \mathrm{~min}$ ) during intravenous glucose tolerance testing increased during glipizide, but not during tolbutamide therapy. Post prandial insulin increments over basal during an oral glucose tolerance test also increased during glipizide, but not tolbutamide therapy. Both drugs were comparable with regard to efficacy and safety; however, only glipizide had chronic effects upon insulin secretion.

Key words: Glipizide, glucagon, insulin, insulin sensitivity, maturity onset diabetes, oral hypoglycaemic agents, tolbutamide.

The chronic hypoglycaemic effects of the sulphonylureas depend upon the presence of the drugs in the circulation as well as the secretion of insulin [1]. It has however been difficult to demonstrate that such agents chronically alter insulin secretion or secretory dynamics [2, 3]. Contradictions concerning the presence or absence of long term effects on insulin may be due to use of differing secretogogues, routes of administration, or differences in drug action. Drug effects upon monocyte receptors and glucagon responsiveness to a protein stimulus have also been reported $[4,5,6]$. The purpose of the present studies was to explore the hypoglycaemic mechanisms of an established (tolbutamide) and newer (glipizide) sulphonylurea in two comparable groups of maturity onset diabetic patients.

The former has not been shown to have chronic effects on insulin secretion [7] while the latter has been shown to be the most potent sulphonylurea on a weight basis as well as having marked effects upon insulin in short term studies [8]. An open, parallel, comparative trial of tolbutamide and glipizide was carried out in patients with persistent fasting hyperglycaemia during a four week diet-placebo period. During active drug treatment, fasting and two hour post prandial serum glucose levels were assessed at monthly intervals throughout a six month treatment program. Insulin secretion and dynamics and glucose disappearance rates $(\mathrm{Kg})$ were studied before and at the end of the sixth month of therapy.

\section{Materials and Methods}

\section{A. Patient Selection}

Patients included in this study were male and female adults (who used contraceptives or were unable to bear children) above 30 years of age whose life expectancy was estimated to be at least five years. Such individuals had documented maturity onset diabetes as confirmed by an oral glucose tolerance test (OGTT) on admission to the diet screening phase of the study. United States Public Health Service criteria were used for oral glucose tolerance testing as adapted for serum glucose [9]. Informed consent was obtained at the first visit and an estimate was made of the patient's capability to comprehend and adhere to diet and medication schedules. Exclusion and inclusion criteria for the diet screening phase of the 
Table 1. Inclusion and exclusion criteria ${ }^{a}$

\begin{tabular}{|c|c|}
\hline Inclusion & Exclusion \\
\hline 1. Over age 30 & $\begin{array}{l}\text { 1. Juvenile-onset or unstable } \\
\text { diabetes mellitus }\end{array}$ \\
\hline $\begin{array}{l}\text { 2. Diagnosis confirmed by } \\
\text { OGTT }\end{array}$ & $\begin{array}{l}\text { 2. Hepatic or renal insuffi- } \\
\text { ciency }\end{array}$ \\
\hline $\begin{array}{l}\text { 3. Life expectancy of five years } \\
\text { or more }\end{array}$ & 3. Use of diabetogenic drugs \\
\hline $\begin{array}{l}\text { 4. Ability to adhere to diet and } \\
\text { medication regimens }\end{array}$ & $\begin{array}{l}\text { 4. History of drug abuse or } \\
\text { non-compliant behaviour } \\
\text { 5. Previous sulphonylurea } \\
\text { therapy failure }\end{array}$ \\
\hline
\end{tabular}

a Abbreviation used: OGTT, oral glucose tolerance test

study are summarized in Table 1 . Twenty-nine individuals were maintained on either tolbutamide or glipizide. Eleven individuals had missing data, were lost to follow-up, had to discontinue drug, and/or declined to continue in the study for its full duration. Eighteen completed the study and are described in detail. Patients were recruited from the population of the diabetes clinic of the Boston City Hospital and studied in the ambulatory facility of the Thorndike General Clinical Research Center for Boston University Medical Center at Boston City Hospital.

\section{B. Experimental Design}

The study consisted of a diet screening-placebo phase, a baseline evaluation, drug titration, and maintenance periods, and a final evaluation. The screening phase lasted six weeks or less and encompassed a maximum of seven weekly visits. At the first visit patients discontinued any diabetic medications. At that visit they underwent a $100 \mathrm{~g}$ oral glucose tolerance test (OGTT) and were then placed on a diet designed to achieve and maintain ideal body weight $( \pm 5 \%)$ (Metropolitan Life Insurance Co.). The diet consisted of $45 \%$ carbohydrate, $20 \%$ protein and $35 \%$ fat. After receiving a supply of placebo drug the patients were instructed to take one tablet daily before breakfast. At each diet screening visit, fasting and two hour post prandial serum glucose concentrations were determined. The patient's weight was recorded, urinalysis performed for glucose and acetone and an interim history obtained. Serum obtained at these visits was frozen and saved for determination of insulin concentrations. Patients were admitted to the drug titration phase when they exhibited three fasting serum glucose concentrations, of greater than $130 \mathrm{mg} / \mathrm{dl}$ and less than $230 \mathrm{mg} / \mathrm{dl}$, the last two of which were consecutive. Before being given active drug, patients underwent a baseline evaluation and an intravenous glucose tolerance test (IVGTT). Specimens were subsequently analyzed for glucose, insulin and glucagon concentrations. Patients then entered the active drug titration phase and were assigned consecutive numbers which were matched with a corresponding list of computer generated random drug assignments.

The drug titration phase lasted until maximum control of fasting hyperglycaemia was obtained, or a maximum tolerated dose was reached. The largest daily doses of glipizide and tolbutamide prescribed were $40 \mathrm{mg}$ and $3 \mathrm{~g}$. Glipizide was supplied as scored 5 and $10 \mathrm{mg}$ tablets, tolbutamide as $500 \mathrm{mg}$ tablets. The drugs were administered in divided doses. During the drug titration phase patients were seen weekly, when fasting and two hour post prandiat glucose concentrations were obtained (after a $100 \mathrm{~g}$ glucose load). Laboratory screening was done at every other visit beginning with the second titration visit. This consisted of a complete blood count, serum alanine and aspartate aminotransferases bilirubin, albumin and globulin, electrolytes, cholesterol and triglyceride concentrations.

After maximum control or maximum dose was reached for two consecutive weekly visits, the patient entered the drug maintenance phase. Patients were seen at two week intervals for the first two maintenance visits and thereafter monthly. The active drug phase lasted for a total of six months or until discontinuation for other reasons. At each maintenance visit, fasting and post prandial glucose concentrations were obtained as described above. Active drug was administered after obtaining fasting blood specimens and prior to glucose administration. Laboratory screening was carried out after the second week and second month on drug maintenance and at the final visit of the study. ECG and ophthalmologic examinations were performed before and after six months of drug. At the termination visit of the study an IVGTT was also done.

\section{Laboratory and Data Analysis}

During the OGTT serum samples were obtained for glucose and insulin concentrations at $0,30,60,90,120$ and $180{\text { min. Kolade }{ }^{\mathbb{B}}}$ $(120 \mathrm{ml})$, which contains $100 \mathrm{~g}$ of glucose, was drunk over a $10 \mathrm{~min}$ period. The IVGTT in the study utilized $0.375 \mathrm{~g}$ glucose $/ \mathrm{kg}$ body weight injected IV over 2 min [10]. Samples were collected from a vein of the opposite arm at $0,2,4,6,10,20,30,40,60$, and 90 min after beginning glucose injection. Whole blood $(2 \mathrm{ml})$ was collected in iced EDTA tubes to which 1000 units of aprotinin had been added [11]. This specimen was then centrifuged at $4^{\circ} \mathrm{C}$ and the plasma frozen at $-20^{\circ} \mathrm{C}$ for glucagon analysis. Blood samples $(3 \mathrm{ml})$ were placed in dried tubes to clot at $4^{\circ} \mathrm{C}$. After separation, the serum was separated and frozen at $-20^{\circ}$ for determination of insulin. At titration and maintenance visits patients had samples obtained for analysis of fasting and two hour postprandial serum glucose and insulin levels. Serum glucose was measured at each visit by means of a Beckman Glucose Analyzer. Glucagon and insulin samples in a given patient were run in the same assay by previously published methods $[12,13]$. The minimum detectable glucagon concentration in this assay is $25 \mathrm{pg} / \mathrm{ml}$ ( $5 \mathrm{pg} / \mathrm{tube})$ and the coefficient of variation is $10 \%$ at $50 \mathrm{pg} / \mathrm{ml}$ and $5 \%$ from 100 to $1000 \mathrm{pg} / \mathrm{ml}$. Unger's $30 \mathrm{~K}$ antiglucagon serum was used. ${ }^{125} \mathrm{I}$ insulin and glucagon were obtained from New England Nuclear, Boston, Massachusetts, U.S.A. Glucose disappearance rates were determined by calculation of the slope of log. glucose concentrations in $\mathrm{mg} / \mathrm{dl}$ from the 10 th through 60 th min after beginning glucose injection [14].

Baseline glucose and insulin concentrations referred to in the text are the means of concentrations obtained during the screening period. Each mean was derived from a minimum of three observations. Statistical analysis was carried out by paired $t$ tests. When noted, non-parametric techniques were used [15].

\section{Results}

The two drug groups were well-matched for age, sex, and previous therapy (Table 2). The difference in duration of diabetes was 4.8 versus 9.4 years for glipizide and tolbutamide groups. The longest duration in the former was 15 years whereas two individuals in the latter group had diabetes for 20 years. $\% /$ ideal body weight also differed with five of the glipizide group and three of the tolbutamide group exceeding $115 \%$. However the differences between 
Table 2. Baseline characteristics ${ }^{\mathrm{a}}$

\begin{tabular}{|c|c|c|c|c|c|}
\hline \multicolumn{6}{|c|}{ Tolbutamide group } \\
\hline No. & $\begin{array}{l}\text { Age } \\
\text { (years) }\end{array}$ & Sex & $\begin{array}{l}\text { Duration of } \\
\text { diabetes } \\
\text { (years) }\end{array}$ & $\begin{array}{l}\text { \% ideal } \\
\text { body } \\
\text { weight }\end{array}$ & $\begin{array}{l}\text { Previous } \\
\text { therapy }\end{array}$ \\
\hline 01 & 61 & M & 3 & 114 & Tolbutamide \\
\hline 02 & 47 & M & 12 & 113 & Insulin \\
\hline 03 & 83 & $\mathrm{~F}$ & 20 & 125 & Tolazamide \\
\hline 04 & 67 & M & 6 & 132 & Tolbutamide \\
\hline 11 & 75 & M & 7 & 95 & Tolbutamide \\
\hline 13 & 60 & M & 10 & 92 & Insulin \\
\hline 17 & 71 & $\mathrm{~F}$ & 20 & 102 & $\begin{array}{l}\text { Tolbutamide } \\
\text { Phenformin }\end{array}$ \\
\hline 20 & 63 & $\mathrm{M}$ & 11 & 98 & Diet \\
\hline 23 & 53 & M & 3 & 118 & Tolbutamide \\
\hline 27 & 60 & M & 2 & 106 & Diet \\
\hline \multicolumn{6}{|c|}{ Mean $\pm S E M$} \\
\hline & $64 \pm 3$ & & $9 \pm 2$ & $110 \pm 4$ & \\
\hline
\end{tabular}

Glipizide group

\begin{tabular}{|c|c|c|c|c|c|}
\hline No. & $\begin{array}{l}\text { Age } \\
\text { (years) }\end{array}$ & Sex & $\begin{array}{l}\text { Duration of } \\
\text { diabetes } \\
\text { (years) }\end{array}$ & $\begin{array}{l}\% \text { ideal } \\
\text { body } \\
\text { weight }\end{array}$ & $\begin{array}{l}\text { Previous } \\
\text { therapy }\end{array}$ \\
\hline 05 & 67 & $\mathrm{M}$ & 15 & 126 & Diet \\
\hline 07 & 75 & M & 2 & 150 & Chlorpropamide \\
\hline 12 & 45 & M & 5 & 112 & $\begin{array}{l}\text { Tolbutamide/ } \\
\text { Phenformin }\end{array}$ \\
\hline 14 & 58 & $\mathrm{~F}$ & 1 & 129 & Insulin \\
\hline 18 & 48 & $\mathrm{~F}$ & 1 & 115 & Diet \\
\hline 19 & 67 & M & 7 & 116 & Tolbutamide \\
\hline 21 & 65 & M & 3 & 118 & Diet \\
\hline 26 & 65 & M & 4 & 107 & Diet \\
\hline \multicolumn{6}{|c|}{ Mean $\pm S E M$} \\
\hline & $61 \pm 4$ & & $5 \pm 1$ & $122 \pm 5$ & \\
\hline
\end{tabular}

${ }^{a}$ Mean and SEM are rounded to the nearest whole number

groups were not significant using the Mann-Whitney U test. Data was also reanalyzed in both groups with the heaviest individual ( $150 \%$ of ideal weight) eliminated from the glipizide group and the two individuals with diabetes of the longest duration excluded from the tolbutamide group. The results and conclusions reached were not changed by such reanalysis.

Mean pre-drug fasting and two hour post-prandial serum glucose concentrations for both the glipizide and tolbutamide subjects were virtually identical (see Fig. 1). Fasting serum levels of glucose were $190 \pm 7$ and $173 \pm 8 \mathrm{mg} / \mathrm{dl}$ respectively. Postprandial concentrations of glucose were $318 \pm 25$ and $336 \pm 28 \mathrm{mg} / \mathrm{dl}$.

Mean $\%$ change from baseline glucose concentrations for fasting and two hour post prandial glucose concentrations are shown in Table 3. During the second month of therapy, one tolbutamide treated indi-

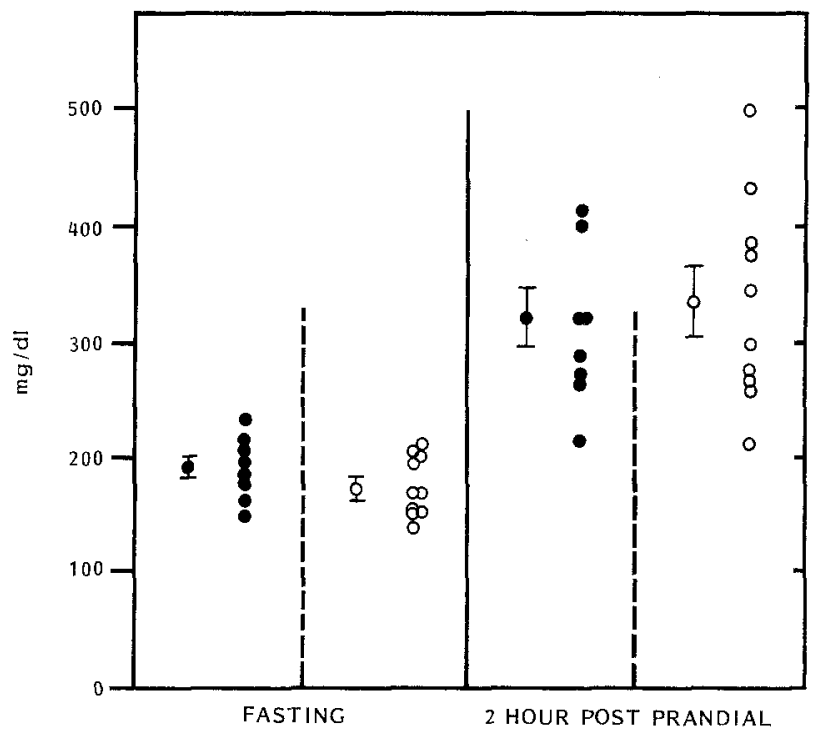

Fig. 1. Baseline (pre-drug) serum glucose concentrations in $\mathrm{mg} / \mathrm{dl}$. Mean concentrations are given for the individuals to be treated with glipizide (closed circles) or tolbutamide (open circles). Mean values for each group \pm SEM are also shown to the left of each set of data

vidual who was responsive during the first month of therapy had an increase in glucose levels of $>10 \%$ over basal. Therefore data with regard to fasting and $2 \mathrm{~h}$ post-prandial plasma glucose levels were deleted for this patient from the second to sixth months of therapy. Tolbutamide was continued since the patient refused insulin therapy and was stable. The mean overall decrease in fasting glucose concentrations on glipizide was $25 \pm 2 \%(p<0.001)$ which was significantly greater than the reduction while on tolbutamide of $17 \pm 2 \%(\mathrm{p}<0.025)$.

Overall decreases in two $h$ post-prandial glucose levels were similar for both sulphonylureas: $12 \%$ and $10 \%$ for glipizide and tolbutamide respectively. Decreases in fasting glucose levels were greater than decreases in post-prandial levels for both groups ( $\mathrm{p}<0.001$ and $<0.025$, respectively).

Glucose disappearance rates $(\mathrm{Kg})$ for individuals and for the groups before treatment and while on drugs are shown in Figure 2. Mean $\mathrm{Kg}$ for the glipizide treated patients increased from a pre-drug value of $0.47 \pm 0.04 \% / \mathrm{min}$ to $0.85 \pm 0.08 \% / \mathrm{min}$ on glipizide. In the tolbutamide treated patients, $\mathrm{Kg}$ increased from a baseline value of $0.47 \pm 0.08 \%$ to $0.70 \pm 0.11 \% / \mathrm{min}$. Both increases were highly significant $(\mathrm{p}<0.005$ and $<0.01)$.

Early insulin release (Fig. 3 a) in response to the IV glucose load was assessed by summing the change in insulin concentrations over fasting levels at 2, 4, 6, and $10 \mathrm{~min}$ after beginning a 2 min injection of glu- 
Table 3. Percent decrease in glucose concentrations during drug therapy ${ }^{\mathrm{a}}$

\begin{tabular}{llllllll}
\hline Fasting & \multicolumn{1}{l}{} \\
\hline Month & 1 & 2 & 3 & 4 & 5 & 6 & Mean \\
\hline Glipizide & $20 \pm 7$ & $30 \pm 2$ & $31 \pm 5$ & $23 \pm 7$ & $24 \pm 6$ & $21 \pm 8$ & $25 \pm 2$ \\
$\mathrm{p}^{\mathrm{b}}$ & 0.025 & 0.001 & 0.001 & 0.01 & 0.005 & 0.025 & 0.001 \\
Tolbutamide & $7 \pm 4$ & $16 \pm 5$ & $21 \pm 4$ & $24 \pm 4$ & $16 \pm 6$ & $20 \pm 5$ & $17 \pm 2$ \\
$\mathrm{p}^{\mathrm{b}}$ & $\mathrm{NS}$ & 0.01 & 0.001 & 0.001 & 0.025 & 0.005 & 0.001 \\
\hline
\end{tabular}

Two hour post oral glucose

\begin{tabular}{llllllll}
\hline Glipizide & \multicolumn{2}{c}{$9 \pm 1011 \pm 9$} & $23 \pm 9$ & $9 \pm 8$ & $6 \pm 6$ & $16 \pm 5$ & $12 \pm 3$ \\
$\mathrm{p}^{\mathrm{b}}$ & $\mathrm{NS}$ & $\mathrm{NS}$ & 0.024 & $\mathrm{NS}$ & $\mathrm{NS}$ & 0.01 & 0.01 \\
Tolbutamide & $10 \pm 4$ & $8 \pm 4$ & $13 \pm 5$ & $10 \pm 6$ & $12 \pm 6$ & $9 \pm 5$ & $10 \pm 1$ \\
$\mathrm{p}^{\mathrm{b}}$ & 0.01 & 0.05 & 0.025 & $\mathrm{NS}$ & 0.05 & $\mathrm{NS}$ & 0.001 \\
\hline
\end{tabular}

a Patient 002 of the tolbutamide group was excluded from analysis for the second through sixth months since his glucose concentrations rose to $10 \%$ above baseline levels during this period

b Probability that mean glucose concentrations have decreased significantly from the placebo-diet control period NS indicates $\mathrm{p}>0.05$

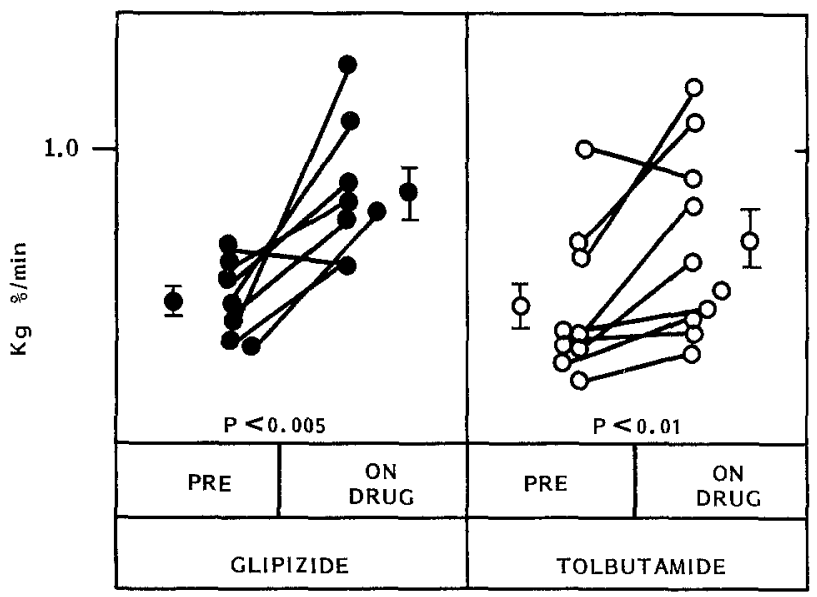

Fig. 2. Glucose disappearance rates $(\mathrm{Kg})$ observed during IVGTT. Individual and mean values are given for each cohort. In the tolbutamide group, one individual had an indeterminate $\mathrm{Kg}$ during the baseline study and is therefore omitted from analysis

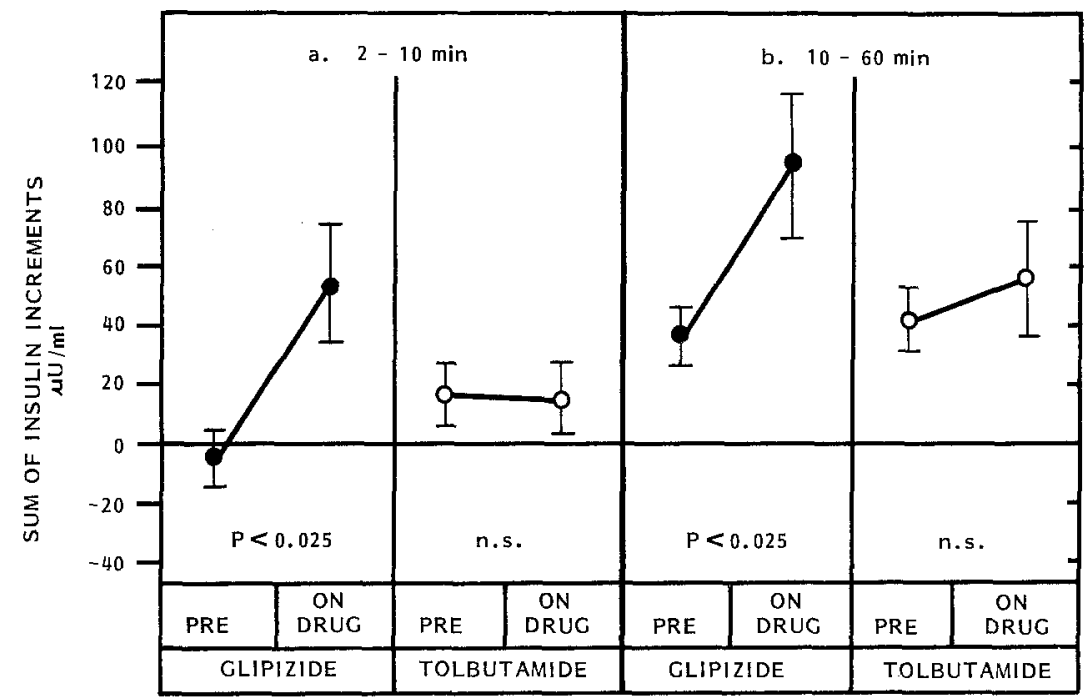

Fig. 3a Early insulin release after glucose injection. The sum of insulin increments over basal ( $\Delta$ insulin $0-10 \mathrm{~min}$ ) in $\mu \mathrm{U} / \mathrm{ml}$ before treatment and while on drugs is shown. $\mathbf{b}$ Late insulin release after glucose injection. The sum of insulin increments over basal ( $\Delta$ insulin $10-60 \mathrm{~min}$ ) in $\mu \mathrm{U} / \mathrm{ml}$ before treatment and while on drugs is shown cose. Glipizide subjects had no detectable early insulin release relative to fasting prior to drug therapy. Differences in early insulin secretion between the two drug groups prior to active agent were not significant. During drug therapy, early insulin release over fasting increased to $54 \pm 20 \mu \mathrm{U} / \mathrm{ml}$ in the glipizide group $(\mathrm{p}<0.025)$. In contrast, tolbutamide treatment did not alter early insulin release significantly, 17 versus $16 \mu \mathrm{U} / \mathrm{ml}$. Late release was also increased significantly by glipizide, but not tolbutamide (Fig. 3 b). For glipizide, the mean pretreatment late insulin increment was $37 \pm 10 \mu \mathrm{U} / \mathrm{ml}$ increasing to $95 \pm 24 \mu \mathrm{U} / \mathrm{ml}(\mathrm{p}<0.025)$ after treat- ment. Mean fasting and two hour post-prandial insulin concentrations before and while on drug are shown in Table 4. Neither drug altered fasting plasma insulin levels significantly, and tolbutamide did not alter insulin release after an oral glucose load. When analyzed in paired fashion, individuals treated with glipizide increased their $2 \mathrm{~h}$ serum insulin concentrations over fasting from $52 \pm 9 \mu \mathrm{U} / \mathrm{ml}$ to $69 \pm 4 \mu \mathrm{U} / \mathrm{ml}$, $(p<0.025)$. Mean weight loss for these groups was virtually identical, $-0.91 \mathrm{~kg}$ for the glipizide and $-1.09 \mathrm{~kg}$ for the tolbutamide treated individuals.

Glucagon suppressibility by hyperglycaemia during IVGTT was studied in two tolbutamide and five 
Table 4. Serum insulin concentrations $\mu \mathrm{U} / \mathrm{ml}$

\begin{tabular}{|c|c|c|c|c|c|c|}
\hline & \multicolumn{3}{|c|}{ Glipizide } & \multicolumn{3}{|c|}{ Tolbutamide } \\
\hline & Before & On drug & $\mathrm{p}^{\mathrm{a}}$ & Before & On drug & $\mathrm{p}^{\mathrm{a}}$ \\
\hline Fasting & $16 \pm 3$ & $17 \pm 3$ & NS & $10 \pm 2$ & $9 \pm 5$ & NS \\
\hline $\begin{array}{l}\text { Two hour pos } \\
\text { glucose meal } \\
\text { Insulin }\end{array}$ & $69 \pm 11$ & $86 \pm 7$ & NS & $54 \pm 9$ & $62 \pm 10$ & NS \\
\hline increment & $52 \pm 9$ & $69 \pm 4$ & 0.025 & $44 \pm 1$ & $52 \pm 10$ & NS \\
\hline
\end{tabular}

${ }^{a}$ Probability that insulin concentrations on drug differ from those measured during the placebo-control period: $\mathrm{p}>0.05$ indicated by NS

glipizide treated individuals. Prior to therapy, there was a small but significant $(\mathrm{p}<0.025)$ decrease in plasma glucagon concentrations during the IVGTT. The maximum suppression in glucagon concentrations was $33 \%$. Mean fasting plasma glucagon concentration prior to drug was $119 \pm 13 \mathrm{pg} / \mathrm{ml}$ and while on drug was $115 \pm 24 \mathrm{pg} / \mathrm{ml}$. On drug, mean suppression of glucagon levels was not significant for any time period.

Three of sixteen individuals treated with glipizide had to discontinue therapy. One patient, although normal on baseline evaluation, sustained a transient increase in serum alanine and aspartate transaminases. This abnormality may have been related to a previous history of liver disease. Two individuals had nausea, vomiting, and diarrhoea. All symptoms resolved within $48 \mathrm{~h}$ of discontinuation of the drug. Eight of the remaining individuals completed the entire experimental protocol and are included in this report. Of the thirteen patients treated with tolbutamide, none had symptoms requiring discontinuation of drug. Ten tolbutamide treated individuals completed the protocol. There were no individuals in either group who demonstrated progression of retinopathy. Serum triglycerides and cholesterol concentrations remained unchanged.

\section{Discussion and Conclusions}

Glipizide was first proposed to be an effective oral hypoglycaemic agent by Ambrogi and co-workers [16]. The dynamics of insulin secretion after a single acute dose of glipizide orally was shown to be similar to that observed after tolbutamide; others demonstrated that peak concentrations of the drug were reached at a similar time after ingestion $[17,28]$. The studies presented here provide evidence that longterm alterations in insulin secretion are observed with glipizide, but not tolbutamide.
Both glipizide and tolbutamide were effective in reducing fasting serum glucose concentrations. This could not be explained by alterations in fasting insulin levels. The decrease in fasting serum glucose concentrations with tolbutamide therapy was clearly less than that for glipizide during the first three months while on drug therapy. However, for the fourth, fifth and sixth months the fall in fasting glucose concentration was similar. The explanation for this difference is not obvious and after six months of therapy these two drugs were equivalent. The overall decrease in two hour post-prandial serum glucose concentrations for both drugs were similar.

In the case of glipizide, post prandial hypoglycaemic activity may be attributable in part to alterations in insulin secretion. This was similar to observations made by Hecht in chlorpropamide treated individuals [2]. However, alterations in insulin secretion are clearly not an absolute necessity for the decrease in glucose concentrations, since in both groups glucose concentrations fell in the absence of changes in fasting serum insulin levels. The recent demonstration that diabetic individuals are characterized by decreased insulin binding to monocytes $[6,19]$ and that treatment with sulphonylureas can enhance binding to such cells, provides a possible explanation for enhanced insulin sensitivity in the absence of changes in insulin concentrations.

A defect in early insulin release after an IV glucose load is a regular feature of diabetes mellitus and has been proposed as a possible causative factor in defective carbohydrate handling [20,21]. Both tolbutamide and glipizide enhanced glucose disappearance rates during therapy. However, tolbutamide did not alter either early or late insulin release. Glipizide, on the other hand, significantly enhanced both early and late insulin release. Tolbutamide and glipizide possess the capacity to alter sensitivity to endogenous insulin, but only one of these agents alters the magnitude of insulin secretion during chronic therapy.

In unpublished data from our laboratory we have noted that the early insulin release in normal individuals, when analyzed as outlined, exceeds late insulin release by a ratio of at least $2: 1$. In diabetic individuals this ratio is less than $1: 1$. This abnormal pattern of insulin release is not altered by sulphonylurea therapy. Both in the case of glipizide and tolbutamide treated patients, late insulin release over basal, both before and on drug was greater than that of early release. Therefore, despite differences between the two drugs in quantitative effects upon insulin release, neither restored insulin secretory patterns to normal.

The mechanism of failure in glucagon suppressibility by hyperglycaemia in diabetes seems related to both a deficiency of insulin per se and also an abnor- 
mality in glucose receptors of the beta cells [22]. The individuals studied in this report had relative preservation of insulin secretion in contrast to the first patients who were described in the literature. Therefore, it was not surprising that these individuals demonstrated suppressibility of glucagon concentrations during hyperglycaemia prior to drug. No consistent changes in glucagon suppressibility were induced by either drug in the small number of individuals studied.

Tolbutamide and glipizide increased insulin sensitivity to endogenous insulin; however, only glipizide had a chronic effect upon insulin secretion. Tolbutamide seems to act primarily by enhancement of sensitivity to endogenous insulin whereas glipizide enhances insulin secretion and may act by both mechanisms.

Acknowledgements. This work was supported in part by grants from the Pfizer Corporation, AR-533 from the General Clinical Research Branch of NIH, AM-21353 from the NIAMDD. The authors wish to thank the excellent technical assistance of Ms. Randi Boxaspen and the secretarial assistance of Ms. Sandra Berry and Ms. Marta Oblack.

\section{References}

1. Karam JH, Matin SB, Forsham PH (1975) Antidiabetic drugs after the University Group Diabetes Program (UGDP). Annu Rev Pharmacol Toxicol 15: 351-366

2. Hecht A, Gershberg H, Hules M (1973) Effect of chlorpropamide treatment on insulin-secretion in diabetics - it's relationship to the hypoglycaemic effect. Metabolism 21: 723-733

3. Barnes A J, Garbien KJT, Crowley MF, Bloom A (1974) Effect of short and long-term chlorpropamide treatment on insulin release and blood glucose. Lancet II: 69-72

4. Ohneda A, Ishii S, Horigome K, Yamagata S (1975) Glucagon response to arginine after treatment of diabetes mellitus. Diabetes 24: 811-819

5. Loreti L, Sugase T, Foa PO (1974) Diurnal variations of serum insulin, total glucagon, cortisol, glucose and free fatty acids in normal and in diabetic subjects before and after treatment with chlorpropamide. Horm Metab Res 5: 278-292

6. Olefsky JM, Reaven GM (1976) Effects of sulfonylurea therapy on insulin binding to mononuclear cells of diabetic patients. Am J Med 60: 89-95

7. Boshell B R, Fox O J, Roddam R F, Hill P S (1967) The effect of sulfonylurea agents on insulin secretion and insulin reserve. Tolbutamide. ... after ten years. Butterfield W J H, Van Westering W (ed). Exerpta Medica Found., Amsterdam, p 286-297

8. Herchuelz A, Malaisse W J (1973) Insulinotropic potency of glipizide in vitro. Diabetologia 9 (Suppl): 309-310

9. Remein Q R, Wilkerson H L C (1961) The efficacy of screening tests for diabetes. J Chronic Dis 13: 6-21
10. Andres R (1971) Effect of age in interpretation of glucose and tolbutamide tolerance tests. In: Fajans S S, Sussman K E (eds) Diabetes mellitus: Diagnosis and treatment. Vol 3, Chapter XX. American Diabetes Association, New York, p 115-120

11. Eisentraut AM, Whissen $N$, Unger $R H$ (1968) Incubation damage in radioimmunoassay for human plasma glucagon and its prevention with "Trasylol". Am J Med Sci 255: 137-142

12. Aguilar-Parada E, Eisentraut A M, Unger R H (1969) Pancreatic glucagon secretion in normal and diabetic subjects. Am J Med Sci 257: 415-419

13. Fineberg S E, Merimee TJ (1973) Effects of comparative perfusions of equimolar, single component insulin and proinsulin in the human forearm. Diabetes 22: 676-686

14. Soeldner J S (1971) The intravenous glucose tolerance test. In: Fajans S S, Sussman KE (eds) Diabetes mellitus: Diagnosis and treatment. Vol 3, Chapter XIX. American Diabetes Association, New York, p 107-113

15. Snedecor G W, Cochran W G (1967) Statistical methods. 6th Ed. Iowa State University Press, Ames, Iowa

16. Ambrogi V, Bloch K, Paturi S, Griggi P, Logmen W, Parenti M A, Rabini T, Tommasin R (1971) Pharmacological study on new oral antidiabetic N-4-Beta-(5-Methyl-Pyrazine-2-Carboxyamido)-Ethyl-Benzene-Sulfonyl-N-Cyclohexyl-Urea or K4204. Arzneim Forsch 21: 208-213

17. Artini D, Abbiati R, Orsini G, Parenti M A, Bloch K, Daturi S, Mandelli V (1973) Pharmacodynamic aspects of 2 sulfonylurea derivatives glipizide and glibencamide. Diabetologia 9 (Suppl): 311-316

18. Schmidt H A E, Schoog M, Schweer K H, Winkler E (1973) Pharmacokinetics and pharmacodynamics as well as metabolism following orally and intravenously administered $\mathrm{C}^{14}$ glipizide, a new antidiabetic. Diabetologia 9 (Suppl): 320-330

19. Goldstein S M, Blecher M, Binder R, Perrino PV, Recant L. (1975) Hormone receptors 5. binding of glucagon and insulin to human circulating mononuclear cells in diabetes mellitus. Endocrinol Res Commun 2: 367-376

20. Seltzer H S, Allen, EW, Herron Jr A L, Brennan M T (1967) Insulin secretion in response to glycemic stimulus: Relation of delayed initial insulin release to carbohydrate intolerance in mild diabetes mellitus. J Clin Invest 46: 323-335

21. Blackard W G, Nelson N C (1971) Portal and peripheral vein immunoreactive insulin concentrations in diabetic subjects. Diabetes 20: $168-170$

22. Gerich J E, Langlois $M$, Naocco C, Lorenzi M, Karam J H Forsham PH (1967) Comparison of the suppressive effects of elevated plasma glucose and free fatty acid levels on glucagon secretion in normal and insulin-dependent diabetic subjects. Evidence for selective alpha-cell insensitivity to glucose in diabetes mellitus. J Clin Invest 58: 320-325

Received: September 14, 1978,

and in revised form: August 29, 1979

Dr. S. Edwin Fineberg

Indiana University School of Medicine

Division of Endocrinology

Department of Medicine

1100 West Michigan Street

Indianapolis, IN 46202

USA 